\title{
WestVirginiaUniversity
}

THE RESEARCH REPOSITORY @ WVU

West Virginia Agricultural and Forestry Experiment

Davis College of Agriculture, Natural Resources

Station Bulletins

And Design

$1-1-1965$

\section{Factors affecting sorption isotherms of alfalfa}

W. R. Guthrie

E. B. Collins

Follow this and additional works at: https://researchrepository.wvu.edu/ wv_agricultural_and_forestry_experiment_station_bulletins

\section{Digital Commons Citation}

Guthrie, W. R. and Collins, E. B., "Factors affecting sorption isotherms of alfalfa" (1965). West Virginia Agricultural and Forestry Experiment Station Bulletins. 514T.

https://researchrepository.wvu.edu/wv_agricultural_and_forestry_experiment_station_bulletins/659 @ WVU. It has been accepted for inclusion in West Virginia Agricultural and Forestry Experiment Station Bulletins by an authorized administrator of The Research Repository@WVU. For more information, please contact ian.harmon@mail.wvu.edu. 
Digitized by the Internet Archive in 2010 with funding from Lyrasis Members and Sloan Foundation 


\section{Factors Affectíng Sorption Isotherms Of Alfalfa}

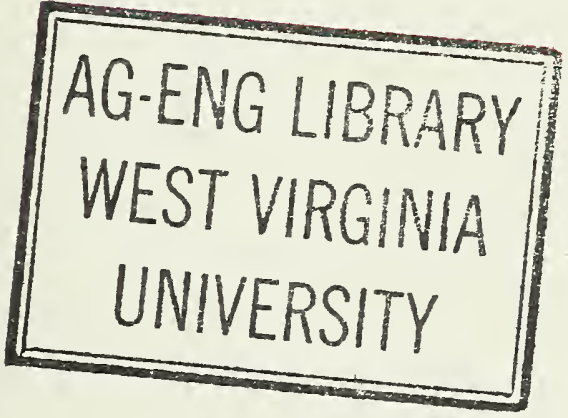

WEST VIRGINIA UNIVERSITY AGRICULTURAL EXPERIMENT STATION BULLETIN 514T NOVEMBER 1965 


\section{THE AUTHORS}

W. R. Guthrie is a former Graduate Assistant; E. B. Collins, formerly Assistant Agricultural Engineer, is now teaching in Egerton College, Njoro, Kenya, East Africa.

BIGGS-JOHNSTON-WITHROW. BECKLEY

WeSt VIRGINIA UNIVERSITY Agricultural Experiment Station COllege of Agriculture and Forestry A. H. Vanlandingham, Director MORGANTOWN 


\title{
FACTORS AFFECTING SORPTION ISOTHERMS OF ALFALFA
}

\author{
W. R. Guthrie and E. B. Collins
}

\section{Introduction}

A review of literature revealed much disagreement in the reported vapor pressure which alfalfa hay will exert in an air atmosphere, at a given moisture content. It was suspected that factors other than temperature and moisture content affected the vapor pressure characteristic.

This sorptive capacity is an indication of the energy required to remove moisture from the material in a drying process. The drying process is important economically not only for alfalfa hay but for many biological materials.

With materials such as cotton (7) and poultry litter (5) the sorptive behavior is generally controlled by, or helps to control, the atmosphere surrounding it. Whether it controls, or is controlled, depends upon the amount of conditioning applied to the atmosphere by external means such as air conditioning or moisture evaporation from the bodies of living animals. Since sorptive capacity of a sorbent in an atmosphere has a direct effect on the condition of that atmosphere, it is desirable to understand the many factors which affect this characteristic.

Besides the two areas mentioned, sorption characteristics of materials are important in reconditioning dried products such as hay, grain, chemicals, and certain freeze-dried vegetables. The direct relationship of the amount of vapor in the surrounding air and the amount of moisture adsorbed by a product allows specific moisture contents to be attained by the product in an atmosphere with a controlled relative humidity.

By measuring the relative humidity of the entrapped air surrounding hygroscopic particles, the value of moisture content corresponding to that relative humidity can be obtained from an equilibrium moisture curve.

Therefore, the sorptive process is one of economic importance and one which has not been adequately defined. The purpose of this investigation was to gain a better understanding of the sorptive process and the factors which affect it. 


\section{Terms and Definitions}

The term "adsorption" refers to the existence of a concentration of any particular component adhering to the surface of a solid. It should be clearly distinguished from absorption, since the latter refers to a more or less uniform penetration. It is, however, difficult to separate the effects of adsorption from those of absorption, even for systems of gases and solids; hence the term "sorption" is sometimes used (8). The term "desorption" is generally used to denote any process by which a material loses water. Sherwood and Comings (9) state that the manner in which moisture moves through a solid and thence out into the air during the drying may be extended to include as a "mechanism" the manner in which gases or vapors move in any transporting process whether it be sorption, desorption, or migration of moisture within the solid. The amount of gas or vapor held by a solid (porous or non-porous) at given conditions of temperature and relative vapor pressure is the equilibrium content of that material. In particular, if water vapor is the sorbate, the weight of water sorbed at a given temperature and relative humidity by a material (the sorbent) is called the equilibrium moisture content (3).

The term "chemisorption" is used to denote the process of absorption where the sorbate is chemically combined with the sorbent. Chemisorption is difficult to distinguish from absorption.

There have been many attempts made to define the sorption process mathematically. Brunauer et al. (4) have developed an equation which adequately defines the sorption of a gas or a solid at low vapor pressures of the gas involved. They assumed that the rate of condensation on top of the first molecular layer of gas is equal to the rate of evaporation from the second layer, etc., and that the heat of sorption is equal to the heat of liquefaction. Based on these assumptions, the following equation was developed:

$$
\frac{\mathrm{f}}{\mathrm{m}(1-\mathrm{f})}=\quad \frac{1}{\mathrm{~cm}_{\mathrm{m}}}=\frac{(\mathrm{c}-1) \mathrm{f}}{\mathrm{cm}_{\mathrm{m}}}
$$

Where $f$ is taken as the vapor pressure ratio $\left(p / p_{0}\right)$ where $p$ is the equilibrium pressure of the test and $p_{0}$ is the saturation pressure, $\mathrm{m}$ is the moisture content (dry basis), $\mathrm{m}_{\mathrm{m}}$ corresponds to the volume of the sorbate making up a unimolecular layer, and $c$ is a constant.

A plot of equation (1) gives a straight line whose intercept is $1 / \mathrm{m}_{\mathrm{m}} \mathrm{c}$ and whose slope is $(\mathrm{c}-1) \mathrm{m}_{\mathrm{m}} \mathrm{c}$. From the slope and intercept, the constants $m_{m}$ and $c$ may be calculated. This equation, referred to as 
the BET equation, plots points very nearly on the original isotherm between the values of .05 and .40 relative vapor pressure.

Smith (10) divided the sorbed water into two categories: that which is in some way bound to the inner or outer surface of the sorbent by forces in excess of the normal forces responsible for condensation of water to the liquid state $\left(w_{\mathrm{c}}\right)$ and that which is normally condensed within the gel $\left(w_{0}\right)$. The total condensate $w$ is then:

$$
\mathrm{w}=\mathrm{w}_{\mathrm{w}}+\mathrm{w}_{\mathrm{w}}
$$

For the case where a gel (sorbent) is assumed to swell only by the addition of discrete pores rather than by enlarging those already present, Smith found the $w$. fraction to be proportional to $-w^{\prime} \ln (1-f)$ where $\mathrm{w}^{\prime}$ comprises those molecules which are normally condensed on the bound water molecules.

Substituting this in equation (2) gives:

$$
w=w_{n}-w^{\prime} \ln (1-f)
$$

A plot of the vapor content (wet basis) versus the natural log of (1-f) is a straight line for most biological materials over the range .5 to .95 vapor pressure ratio.

In the BET theory, the constants of the second and all higher layers are related to each other and to the content of the first layer. In the Smith mathematical treatment, that portion of the sorbate which has the condensation properties of liquid water is isolated on the basis of the manner of its dependance on the relative vapor pressure. The remainder, $w_{b}$, is designated the bound fraction, which is water bound by the affinity existing between the molecules of water and those of the solid on which it is adsorbed.

Becker and Sallans (2) combined the method of Brunaeur et al. with that of Smith in describing the equilibrium isotherm for wheat. The intermediate region of the desorption isotherm is apparently linear. This method for defining the curve in this region results in an excellent fit of the experimental data and gives a smooth unbroken transition into the curved regions described by the BET and Smith equations.

Although these analyses assist materially in defining the nature of the sorption, it must be borne in mind that a plot of actual data is generally necessary. 


\section{Design of Equipment}

Although the gathering of sorption and desorption data is not a new field of research, there is still much disagreement in published data for the same material. Experimental procedure varies greatly among researchers.

It was the purpose of this research to determine some of the factors which affect the sorption isotherm for a particular material-alfalfa hay, and also to establish whether or not variation in test conditions, other than temperature and relative vapor pressure, affect the experimental results greatly.

\section{Drying and Dynamic Isotherm Apparatus}

A constant temperature, constant relative humidity, controlled air flow apparatus was designed and built to dry samples in the same containers used in sorption work. Humidity control was included so that dynamic sorption isotherm data could be obtained with the equipment (Figure 1). The process chosen for controlling relative humidity was the mixing process where part of the air was dried in a silica gel multiple bed dryer and the remainder was by-passed or had steam added to it as necessary. The mixing proportions were controlled by coupling the readout of an AC bridge recorder (used as an indicator for Dunmore humidity sensing elements) to a mixing damper which divided the air stream. The wet air was remixed thoroughly with the dry air by the circulation fan. The volume of moisture which had to be removed from the samples was relatively small (samples were 4-inch cubes), therefore a recirculating process was used so that capacity did not have to be varied with changing atmospheric conditions but only with changing moisture content of the sample. A humidistat using Dunmore elements was used to control adding of moisture via the steamer (which used electric heating elements directly in the water) when relative humidity dropped below the set point. Temperature was controlled by an electronic thermostat using a thermistor sensing element. Heat was added by finned electric strip heaters. It was possible to maintain temperatures to within $1^{\circ} \mathrm{F}$ of the set point over a range of $80^{\circ}$ to $300^{\circ} \mathrm{F}$.

Provision was made for equalizing the static pressure drop across each of four samples by the use of adjustable air flow control gates. The total air flow through the samples was measured in a 3-foot straight duct section with a Hastings Precision Air Meter. Air flow from 10 to about 200 cubic feet per minute per square foot of sample was possible. This was controlled by a simple sliding gate at the fan inlet. 


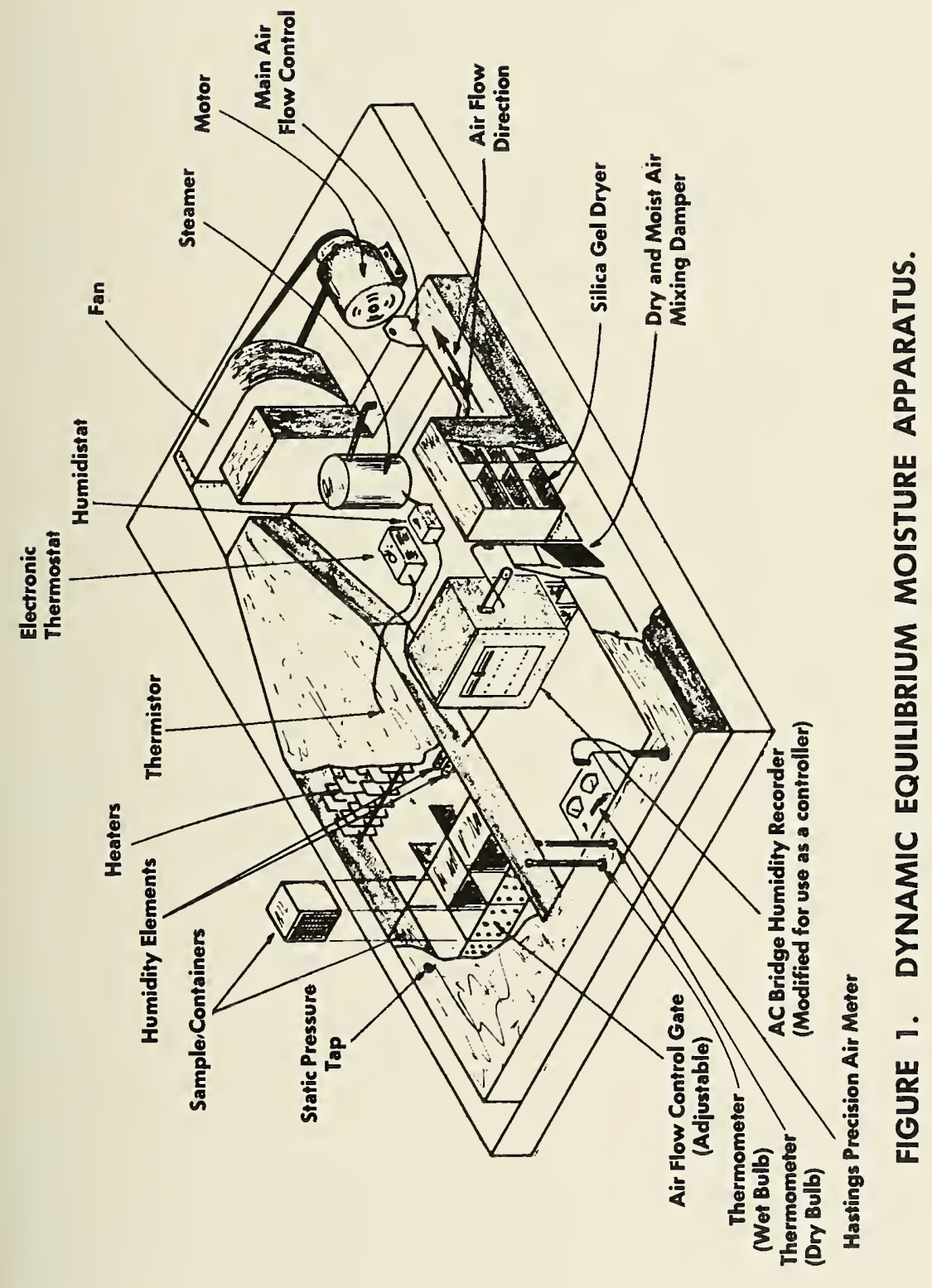




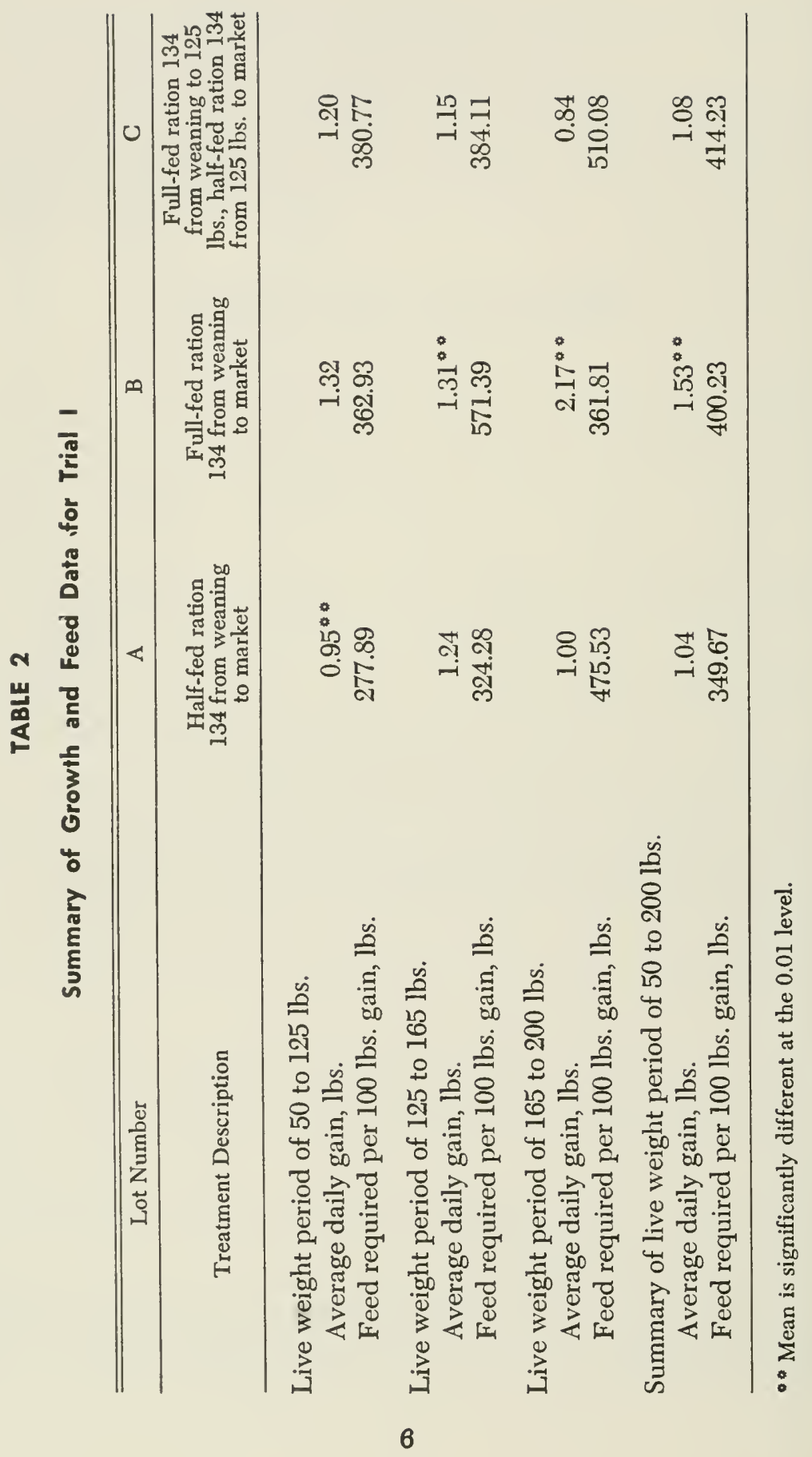




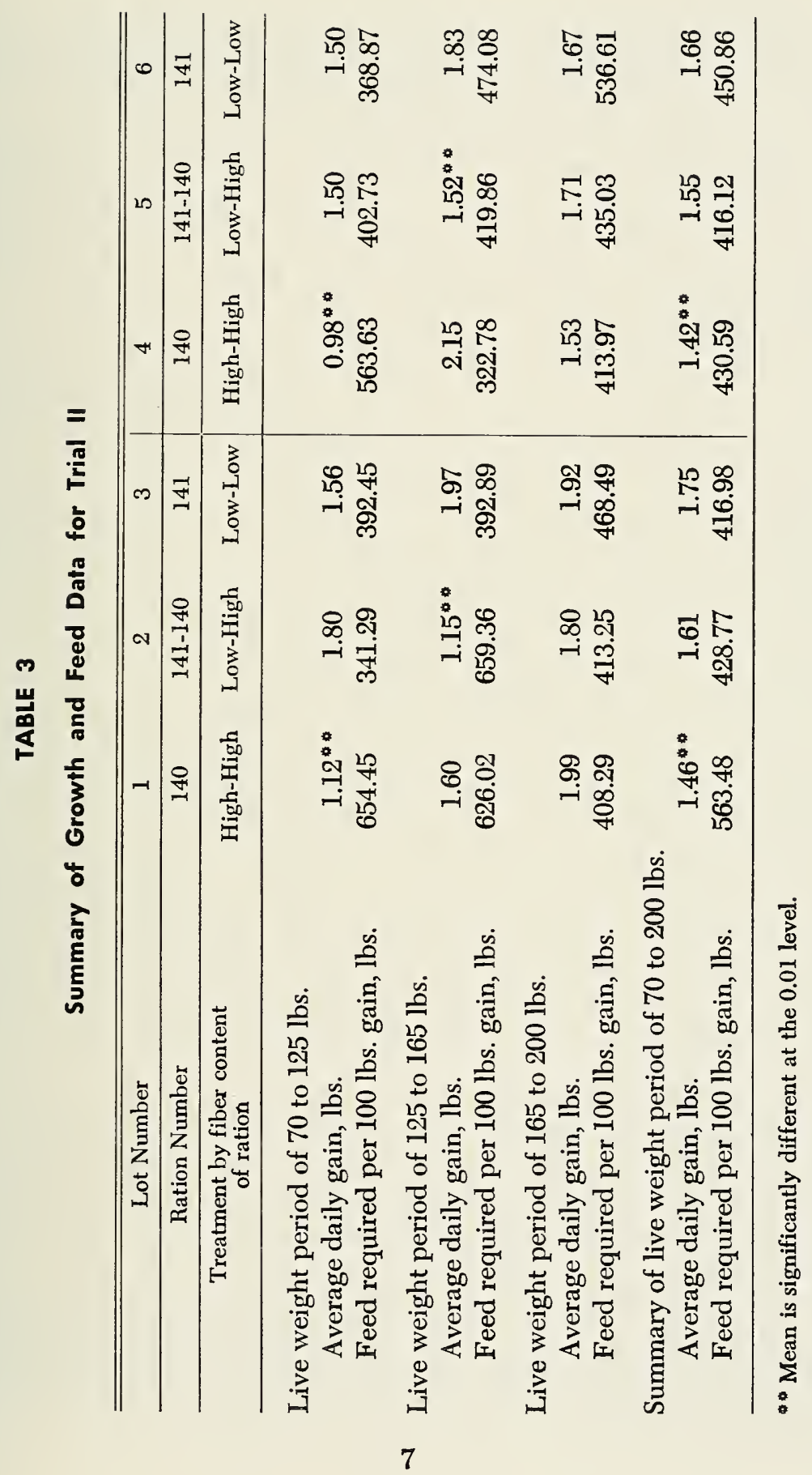


Measurement of relative humidity was with the Dunmore type sensors and an AC bridge. The elements were calibrated periodically. A check on these sensors was made by taking wet and dry bulb temperature each time a relative humidity reading was taken.

\section{Air Flow Control and Measurement}

Air agitation within the controlled atmosphere chamber was accomplished by using a small propeller-type fan. The air speed was measured over the top and the bottom half of the box on a grid system with a Hastings Precision Air Meter and found to be about 100 feet per minute. Agitation was used merely for uniform temperature and humidity condition throughout the chamber.

\section{Measurement of Sample Weight}

A dry glove box was employed which permitted sample weight measurement to be made inside the chamber. This was a long rubber glove, the open end of which was secured to the plexiglass front window of the moisture chamber. Samples were then placed on the scales by hand. Good internal lighting made it possible to weigh as accurately in the box as outside. The scales used were O'Haus with agate bearings, and weights could be taken to the nearest .01 gram.

\section{Calibration of Sensors}

Dunmore humidity sensors were found to exhibit some drift in calibration, therefore it became necessary to recalibrate these elements frequently. The literature investigation revealed that saturated salt solutions exert a partial water vapor pressure which is sufficiently accurate ( $\pm \frac{1 / 2}{2}$ per cent relative humidity at temperature from $50^{\circ}$ to $100^{\circ} \mathrm{F}$ ) to justify their use for a laboratory standard for relative humidity. One limitation is that the solution temperature and that of the controlled atmosphere must be controlled within very close limits $\left( \pm 0.1^{\circ} \mathrm{C}\right)$. The reason for this is that the solution vapor pressure varies linearly with temperature and as a result of fluctuating temperature, a fluctuating relative humidity is obtained. The temperature relative humidity curves were plotted using data taken from Acheson (1) for salts ranging in relative humidity equilibrium from 11 to 95 per cent. A moisture proof chamber was constructed and placed in a temperature control box (Figure 4). Temperature variation was undetectable with a thermometer graduated in $0.1^{\circ} \mathrm{C}$. A centrifugal fan was placed in the chamber so that a steady stream of air was drawn over the sensors being calibrated and passed over the surface of the saturated salt solution which was contained in an 8-inch by 10-inch glass dish. 


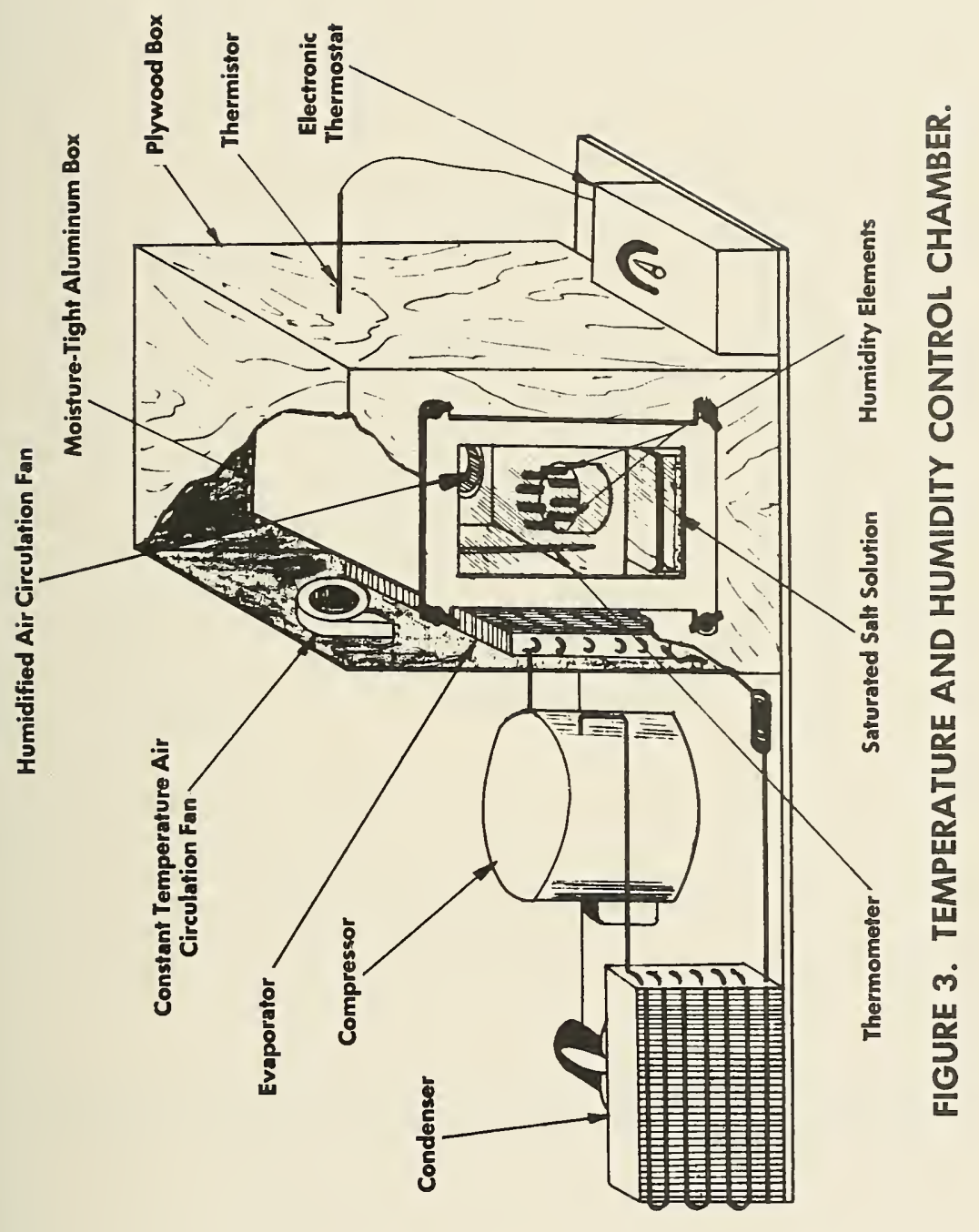




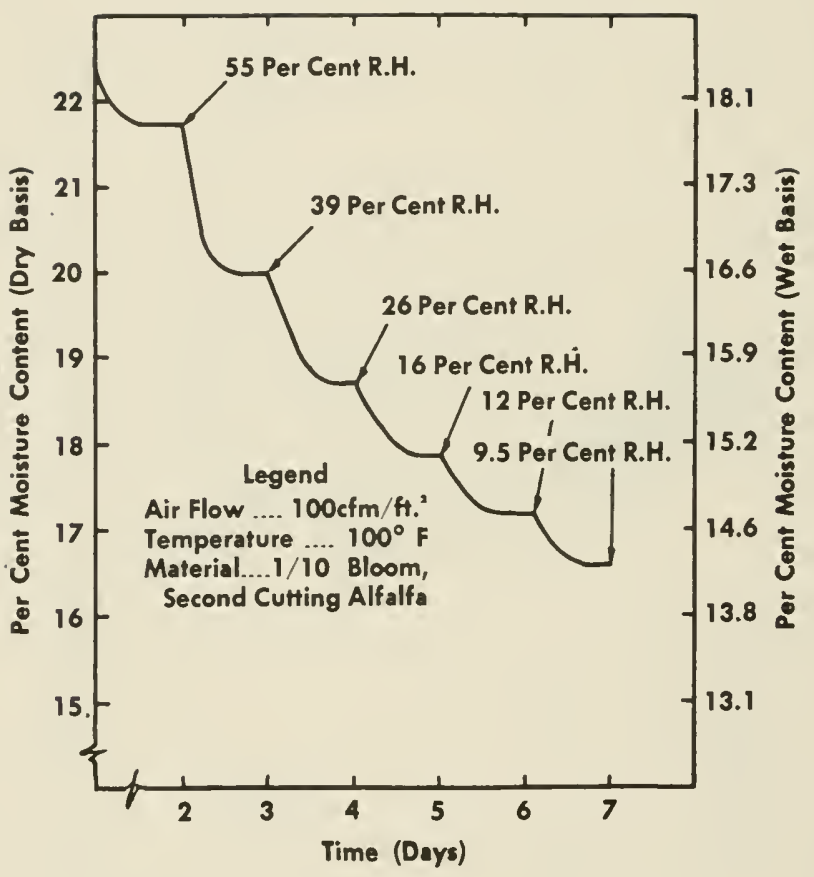

FIGURE 4. CONTROLLED HUMIDITY DRYING CURVE. 


\section{Experimental Procedure}

\section{Sample Procurement}

Vernal alfalfa was used in all tests. The field-grown samples were all obtained from the same plot, which had a clay loam soil, and were taken by the same person. Stage of maturity was observed and recorded; an effort was made to take all samples at as close to $1 / 10$ bloom as possible. The leaf-stem ratio was not determined for each sample since it was felt that it would not vary appreciably on the same plot. No field drying time was allowed in any case. The material was cut and placed directly in plastic bags. Approximately 1 hour elapsed between cutting and the beginning of drying. All field samples were second and third cutting.

Since the study was to continue into the winter, a stand of Vernal alfalfa was established in a greenhouse. This was done even though it was expected that data would differ greatly from that taken with field grown material. The stand was established in a sandy loam soil which had been taken from a woods area. The soil was tested and the recommended amount of lime and fertilizer added. An automatic irrigation system was used to insure a uniform water application. The same cutting procedure was conducted as in the field grown alfalfa.

The greenhouse plot was top dressed with a rate of 200 pounds per acre of 0-20-20 fertilizer after each cut was taken.

\section{Sample Preparation}

Material was cut from the supply plots with garden shears. The height of cut was 2 inches. Any foreign material (tree leaves, weeds, grasses, etc.) was picked from the alfalfa. Diseased or dry plants were also removed. A total of 800 grams was cut to provide for 4 test samples and a moisture sample. All stems (except in the test of long material) were chopped to 1-inch lengths using the shears. The chopped alfalfa was then placed in sample containers which were 4 -inch cubes and made from 1/4-inch mesh welded screen wire. Constant sample density was obtained by placing the same weight of material in each basket, placing a wire mesh cover on the basket, and compressing the material to a uniform dimension with the cover. (Covers could be forced down inside the baskets.) The samples were then ready for the dryer.

\section{Drying Procedure}

The drying and dynamic regain apparatus was used to dry samples for use in the sorption chamber. When this apparatus was used for drying only (especially at high temperatures) the top of the silica gel dryer 


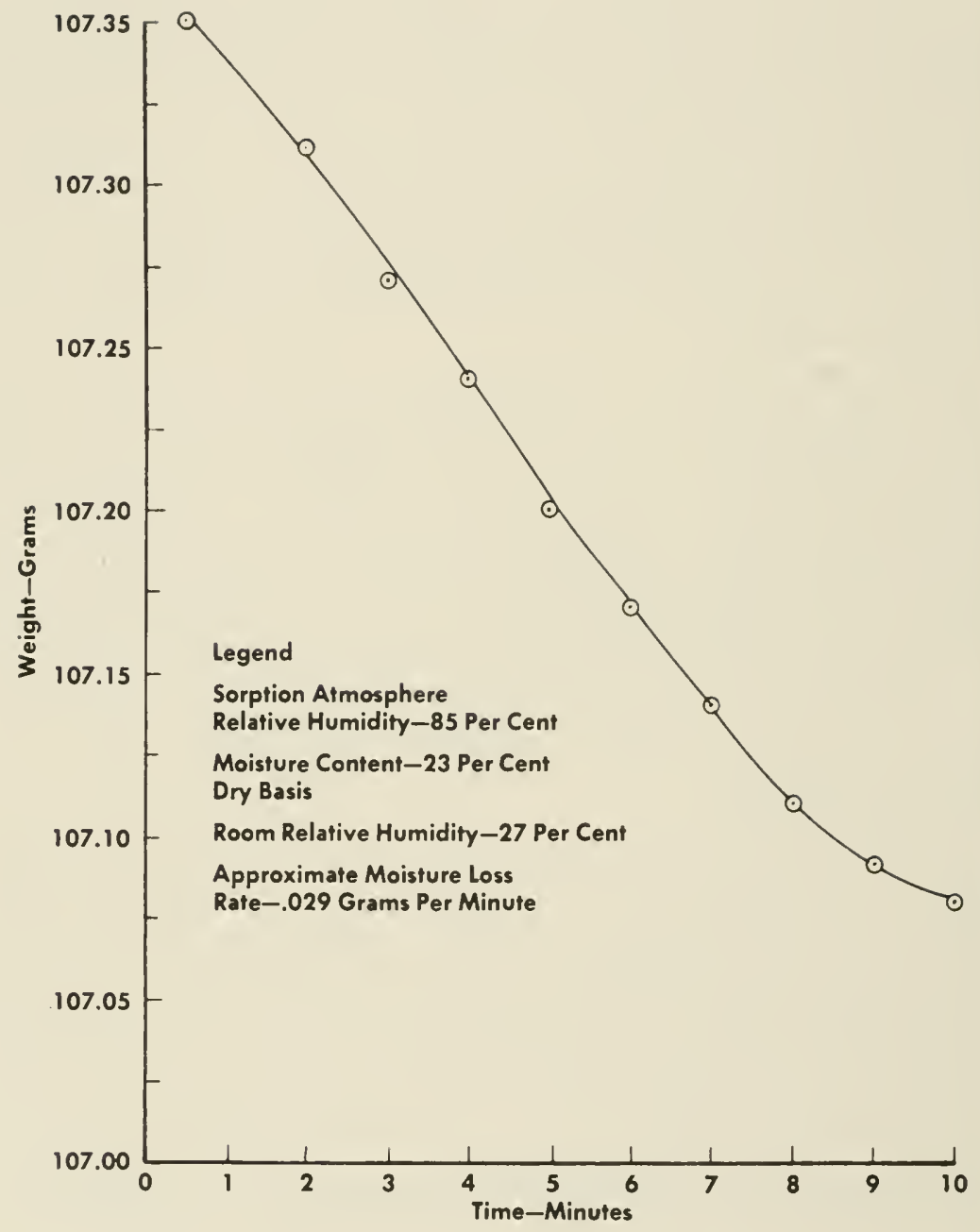

FIGURE 5. WEIGHT LOSS OF HIGH MOISTURE SAMPLE WHEN PLACED IN A LOW HUMIDITY ATMOSPHERE. 
was removed. The air was then exhausted to the atmosphere after passing through the samples and atmospheric air was drawn into the ductwork and heated before passing through the samples. Relative humidity of the drying air was less than 10 per cent in all cases, making it necessary to recirculate the air through the dryer at times when low temperature air was being used. A check was kept on the moisture content of the samples by weighing them periodically. The original moisture content of material placed in the dryer was determined with a Koster Moisture Tester which utilizes the heated air drying principle, and dries rapidly to a constant weight. From these data and the wet weight of the sample the dry weight could be calculated.

When first-desorption data were taken with this apparatus, drying was done with high humidity air until the samples reached a constant weight. The relative humidity was then changed and a new equilibrium established. An example of the step drying curve which can be obtained with this apparatus is shown in Figure 5. This procedure was used only in establishing the minimum moisture content effect. To obtain this curve (see Minimum Moisture Content) the material was dried to equilibrium with air at a given relative humidity. Relative humidity of the drying air was altered and another equilibrium point was reached.

Four samples were dried at a time, thus giving four replications of any set of conditions.

\section{Dynamic Sorption Procedure}

After the dynamic apparatus was built, all material was placed in it after drying and data were taken for the dynamic sorption curve. The air speed was $100 \mathrm{fpm}$. Eight equilibrium points were established in the regain procedure. Samples were removed periodically after air conditions were established and weighed on a trip balance. A curve of moisture loss versus time (Figure 6) for a high moisture content sample in a low relative humidity atmosphere showed that if weighing was completed within 30 seconds less than 0.05 gram error would result. By pre-setting the scales from previous weights for a sample, the time elapsed was less than 5 seconds for obtaining a scale balance. This error is recognized and since it is small it was not eliminated.

Data taken consisted of sample weight at equilibrium; AC bridge reading and corresponding relative humidity; wet and dry bulb temperature; air flow; and, in some cases, time after beginning of test.

\section{Static Sorption Procedure}

Four sets of samples, with four samples per set, were placed in the static sorption chamber. They were distributed so that every fourth 


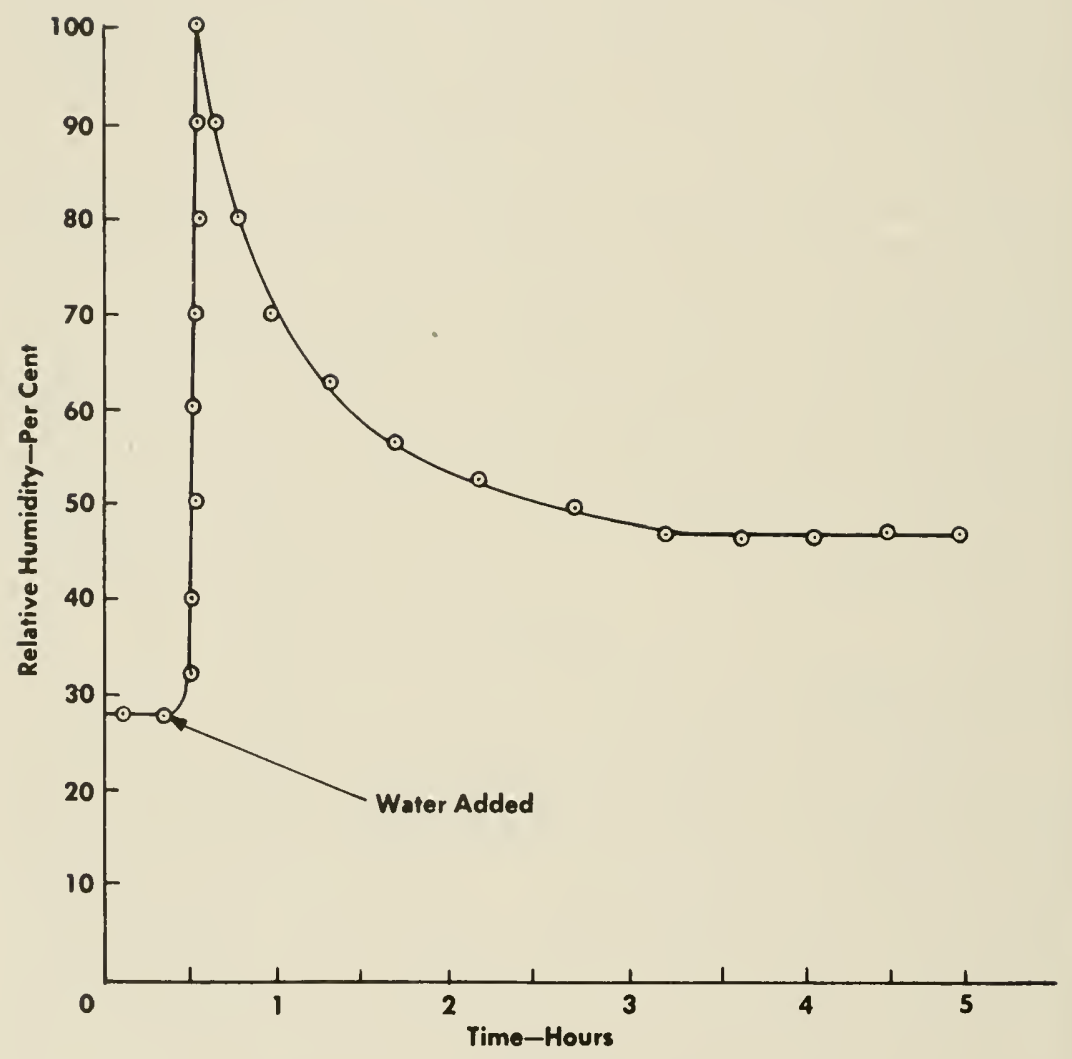

FIGURE 6. HUMIDITY CHANGE RESPONSE OF SORPTION EQUILIBRIUM MOISTURE CHAMBER. 
sample that appeared at the weighing position was one of a set. As soon as samples were in place and the chamber sealed, the drying system was started and allowed to operate until a stabilized relative humidity level was reached. The material was then in equilibrium with the dry air. When no rise in relative humidity occurred, the samples were weighed. Water was added in the chamber by means of the graduated cylinder. The atmosphere was then allowed to reach a steady relative humidity as indicated by the $\mathrm{AC}$ bridge recorder. This usually required about 5 hours (Figure 7). When equilibrium was reached, the samples were weighed and the weight recorded along with the relative humidity, and wet and dry bulb temperatures. Using this technique the regain equilibrium curves were developed.

\section{Sensor Calibration Procedure}

New sensors were used for the first run and were calibrated after the run. Calibration was repeated after each use.

Calibration was carried out by simply placing the sensor to be calibrated in the chamber along with a saturated salt solution exerting a vapor pressure in the range of the sensor. The door was then sealed in place and equilibrium was accomplished in about 10 minutes. Equilibrium was determined by letting the $\mathrm{AC}$ bridge readout print continuously and observing when a constant value was obtained. This value, along with the actual relative humidity was then plotted on the calibration curve and new conditions established with a saturated salt solution having a different vapor pressure.

Temperature was maintained at the same value as that in the apparatus in which the sensor was to be used. 


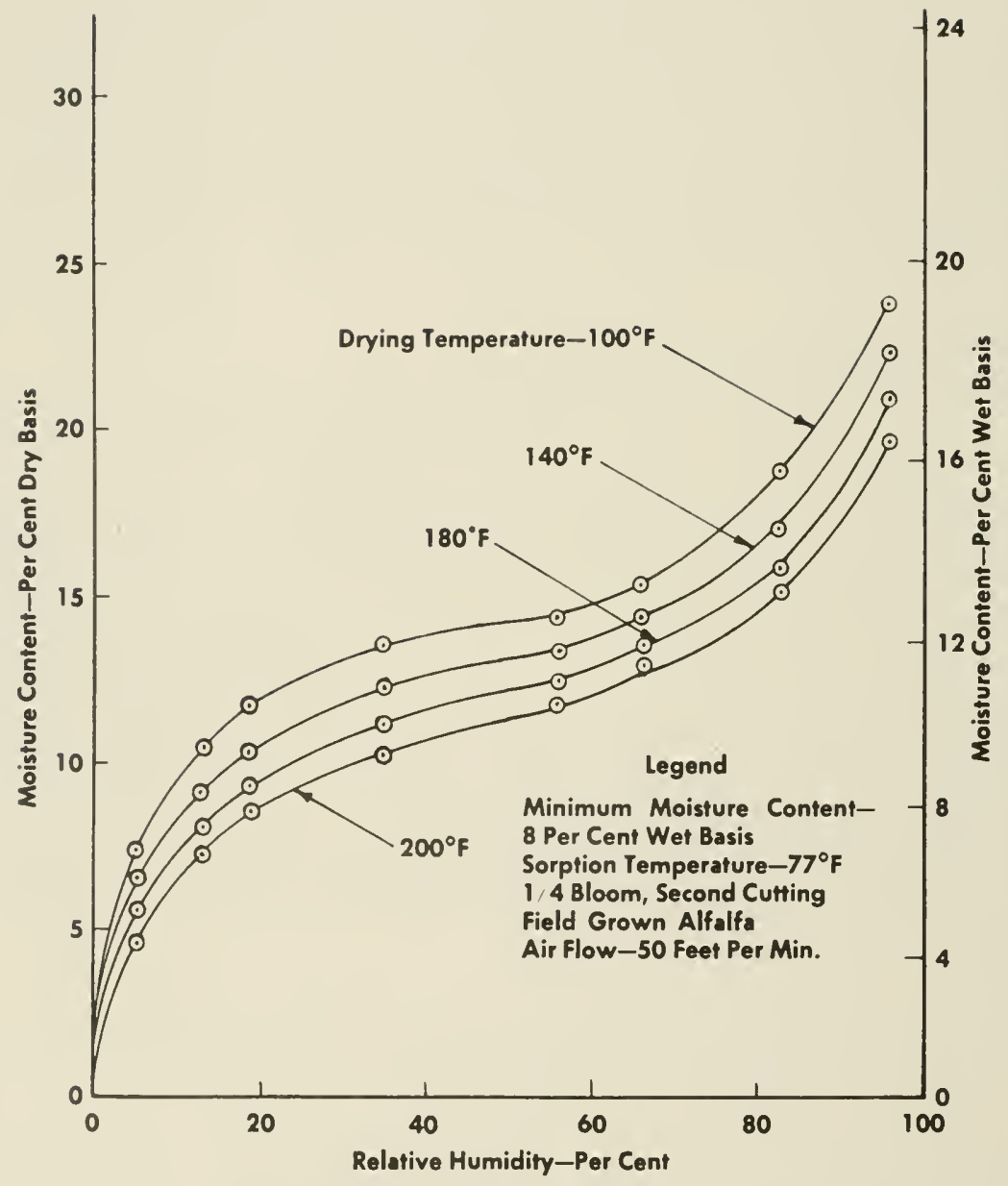

FIGURE 7. SORPTION ISOTHERMS FOR ALFALFA HAY DRIED AT DIFFERENT TEMPERATURES (STATIC). 


\section{Results}

From the weight data taken with both the static and dynamic apparatus and the dry weight after oven drying, the moisture content was calculated on the dry basis. The four values for each set of samples were averaged and the mean plotted versus the corresponding relative humidity. This is the common isotherm plot, and is the form in which all results will be presented. Data were gathered for one temperature $\left(77^{\circ} \mathrm{F}\right)$. The reason was that temperature effect had already been investigated for alfalfa, and the purpose of this research was to discover other factors which affect equilibrium moisture content. Therefore, to get data for which other factors could be compared, one temperature was sufficient and eliminated a variable from the work.

The data for the Brown and BET plots were calculated and plotted. The Henderson equation was not used since it has not been proved general for all temperatures of the sorption atmosphere. From the Brown and BET plots the constants in the corresponding equations were taken and are listed in Table I.

\section{Maximum Drying Temperature Effect}

Field material for this test was dried at temperatures of $100^{\circ}, 140^{\circ}$, and $200^{\circ} \mathrm{F}$. No dynamic regain data were taken for this material since the apparatus used for this had not yet been completed. Samples were dried to 8 per cent wet basis $\pm I$ per cent. Sorption data showed a definite lowering of the sorptive capacity of the alfalfa with increase in drying temperature (Figure 8 ). Drying rate was not determined for the material but drying time varied inversely as with the drying temperature.

The BET and Smith plots (Figures 9 and 10 ) show that the equations fit this material over the range of their applicability. When the sorption isotherms were plotted according to the Smith and BET equations joined by the method of Becker and Sallans and actual data imposed on the curves, all experimental points fitted the curves very well (Figure 11). If $\mathrm{w}_{\mathrm{b}}$ (from the Smith equation) is taken as a measure of effective sorption area, we see that there was a progressive lowering of available sorption area as drying temperature was increased.

One sample was accidentally overdried to about 5 per cent wet basis. This material, which was in all ways similar to the rest of its set, did not regain as much as the others. None of the data for this were used but the occurrence led to the minimum moisture content investigation. 

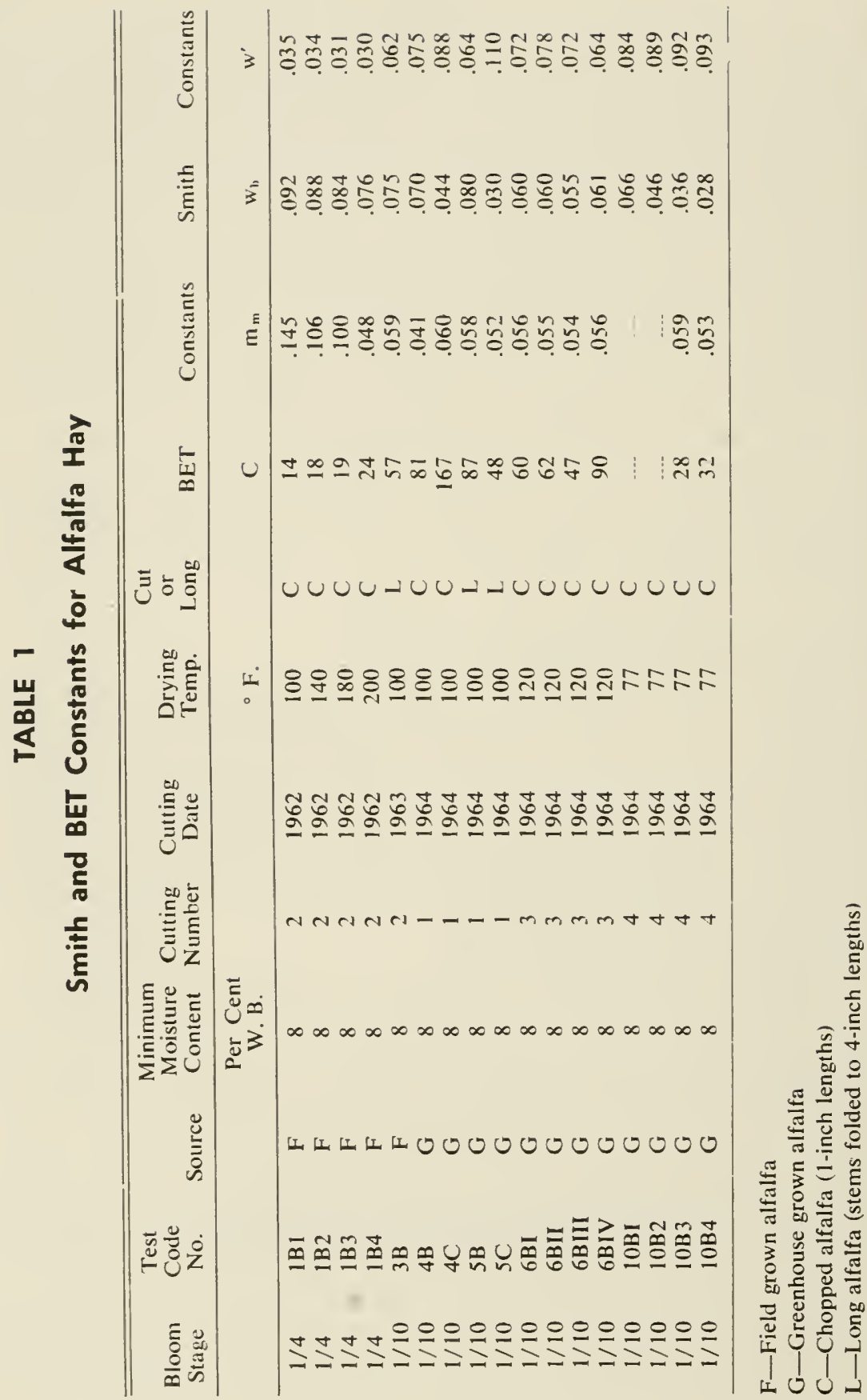


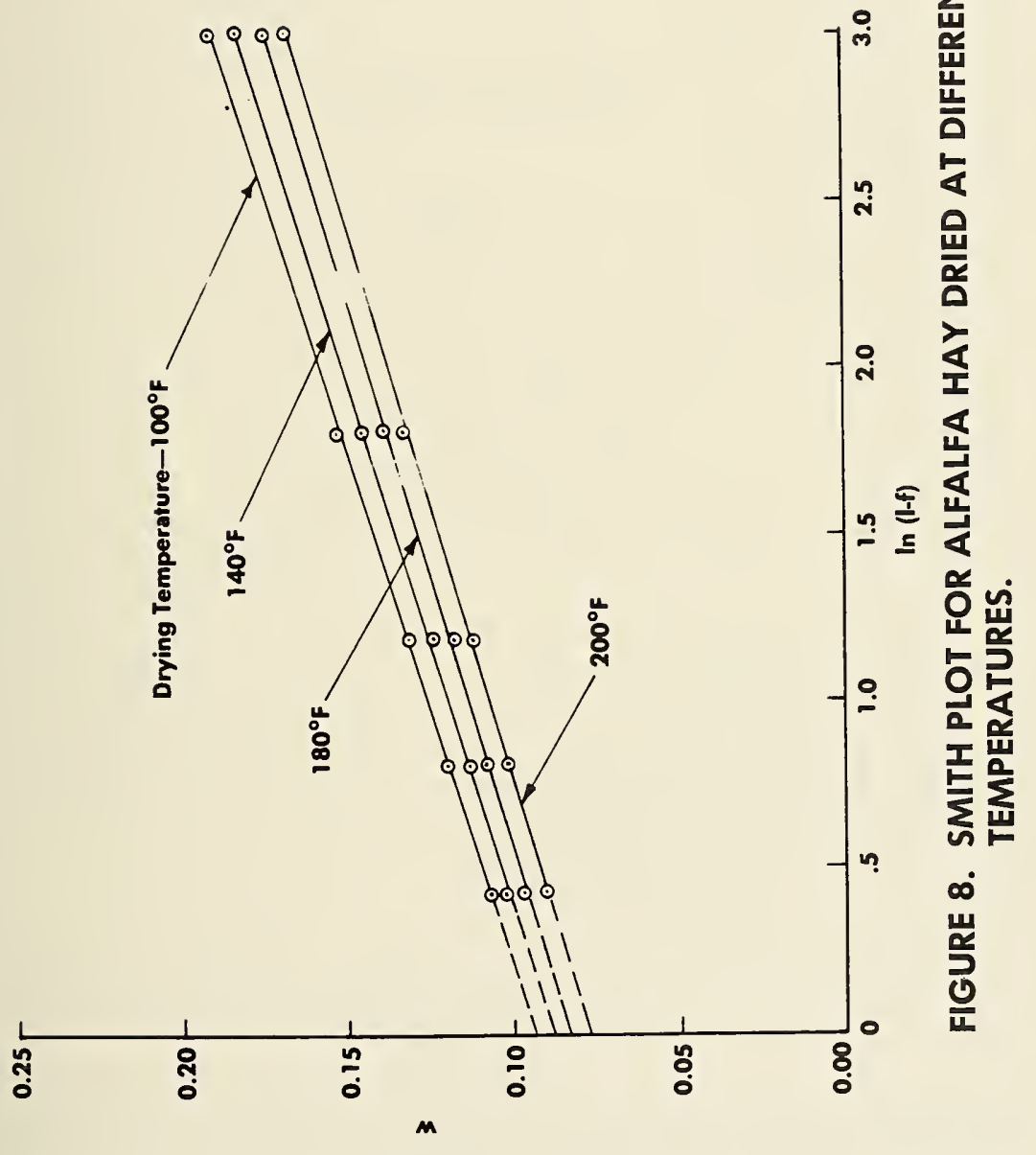




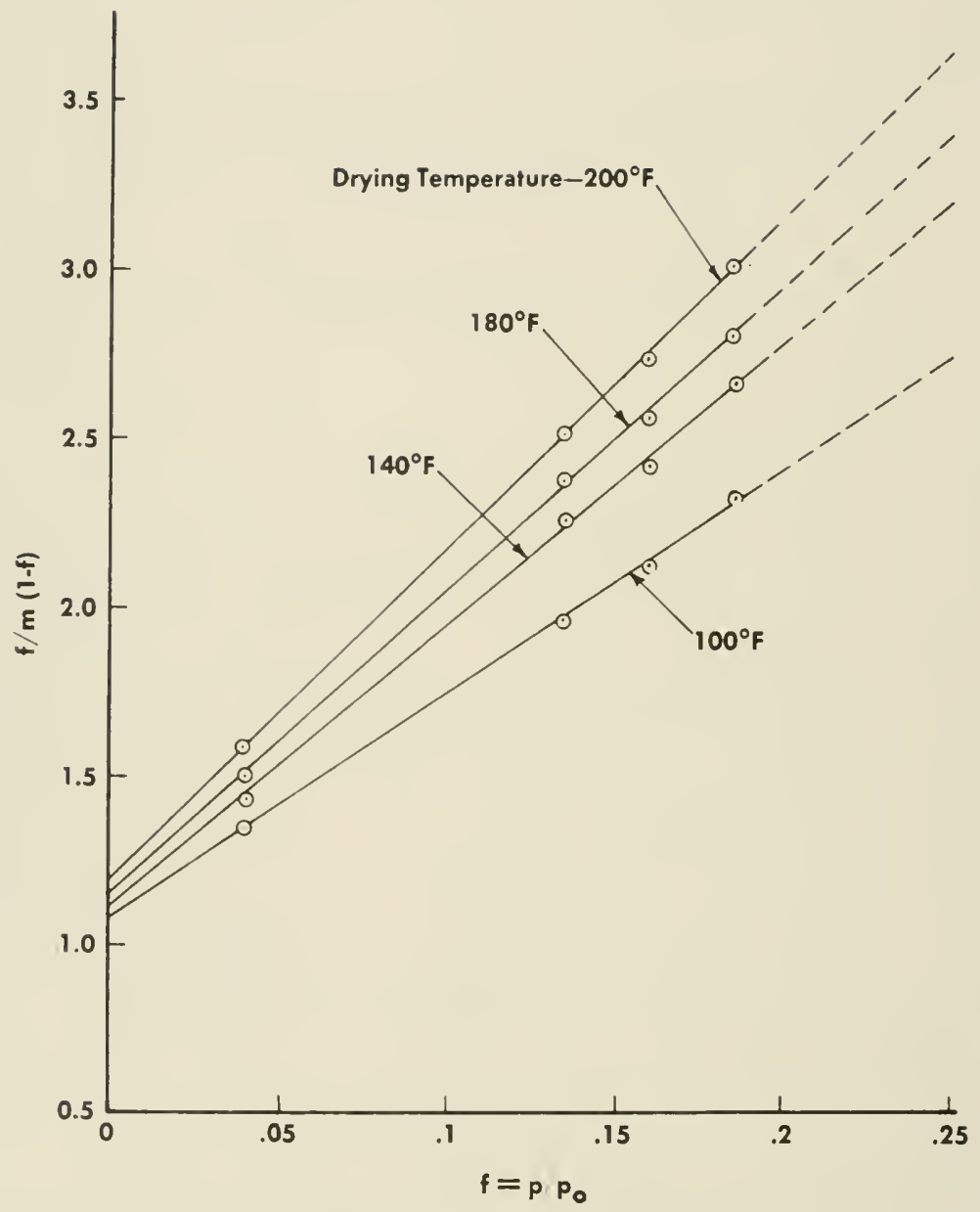

FIGURE 9. BET PLOT FOR ALFALFA HAY DRIED AT DIFFERENT TEMPERATURES. 


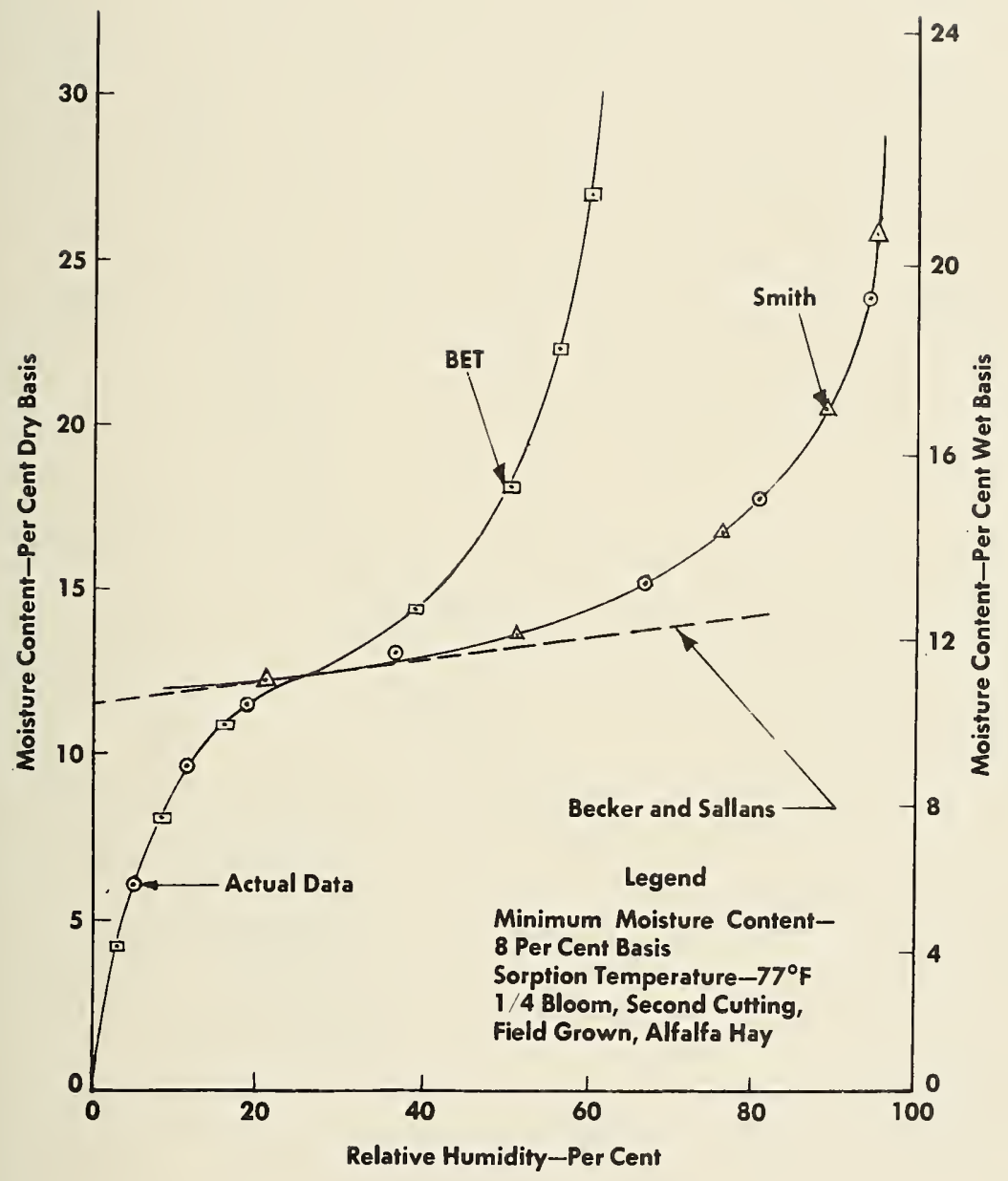

FIGURE 10. FIT OF SORPTION ISOTHERM FOR ALFALFA HAY BY THE BET AND SMITH EQUATIONS JOINED BY THE METHOD OF BECKER AND SALLANS. 


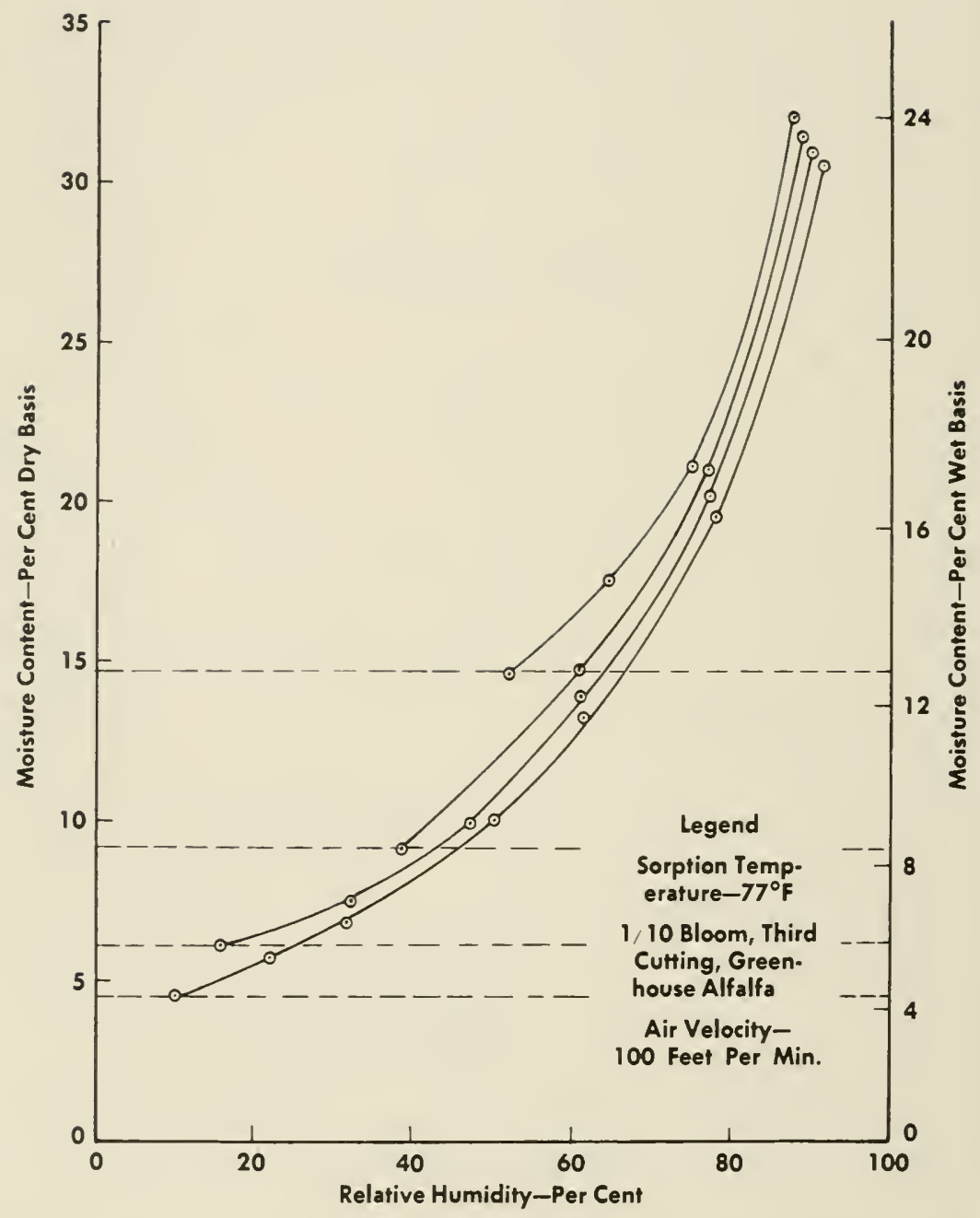

FIGURE 11. DYNAMIC SORPTION ISOTHERMS FOR ALFALFA HAY SHOWING MINIMUM MOISTURE CONTENT EFFECT. 


\section{Minimum Moisture Content Effect}

To investigate the possibilities of an effect on the sorptive capacity of alfalfa from the minimum moisture content to which material was dried, a test was devised using the dynamic sorption apparatus (see Experimental Procedure). Figure 12, which is a plot of the sorption data only (the drying curves were omitted), shows that the drier a sample was before sorption took place, the lower the amount of sorption. This results from mechanical hysteresis. Once cells were deformed by shrinking, the amount to which they would swell (which has been shown to affect sorptive capacity) was affected by the mechanical hysteresis or swelling hysteresis of the cells. Another factor may be simply the forming and breaking of menisci. If this theory is applied to a successively smaller number of points, it would help explain the progressive lowering of the sorptive capacity. The BET and Smith equations constants are shown in Table 1. Again we see a progressive lowering of sorption area with an increase in the initial dryness.

\section{Environment Effect}

Sorption data were taken during the same sorption run for alfalfa grown in the field and greenhouse. The field material was second crop $1 / 10$ bloom as was that from the greenhouse. Both sets of samples were dried at $100^{\circ} \mathrm{F}$ in the dynamic apparatus to the same dryness. Figure 13 shows the sorption isotherms. The field material shows greater sorptive capacity than the greenhouse material. The initial moisture content of the field grown alfalfa was 65 per cent (taken 1 hour after cutting) and that for the greenhouse alfalfa was 75 per cent. Thus the greenhouse material lost more water in coming to a given moisture content than did the field material. This greater loss of water was probably accompanied by greater shrinkage. This could possibly explain the greater sorption of the field material since it did not endure as much shrinkage or physical change of cell walls as did the greenhouse material, thus less swelling was required and less scrption energy taken up in the physical dimension change for a given change in external driving force, that is, relative vapor pressure. There may also have been differences in cell size and, consequently, in number of sorptive points due to thè different growing conditions.

The BET and Smith constants are shown in Table 1.

\section{Sorption with Static and Dynamic Conditions}

Samples of the same material were regained first in the dynamic apparatus with an air velocity of $100 \mathrm{fpm}$ and then in the static 
apparatus with only stirring of air around the samples, but with very little air actually being blown through them. Figure 14 shows the isotherms. There was no noticable difference between the two curves for different air velocity above a relative humidity of 40 per cent. Below this value the sorptive capacity with higher air velocity appeared to be higher. Both the BET and Smith constants indicate that there is a larger effective area available for adsorption with the higher air velocity; that is, the values corresponding to a unimolecular layer are higher when air velocity is increased. The isotherms also tend to show this.

More data need to be analyzed for effects of air velocity before general conclusions can be stated as to its effect, but it may be said that for alfalfa hay the effect of varying air velocity between 0 to 100 $\mathrm{fpm}$ on the sorptive capacity is negligible.

\section{Sorption of Long and Chopped Material}

Two sets of samples of the same material, one chopped to 1-inch lengths and one with the full length stems folded to 4 -inch lengths, were dried at the same rate (and temperature) to equal moisture contents. Both sets were regained in both the dynamic and static apparatus. The points fell on a single curve and no trends are detectable. Figure 15 shows the isotherm for static conditions. The isotherm for dynamic sorption was similar.

The BET and Smith constants show opposite trends due to length of sample stems, the BET showing an increase in unimolecular level with long material and the Smith showing a decrease in unimolecular level with long material.

Again no general conclusions may be stated as to effect of particle size or of cutting material, thus exposing more pores. But, we may say that for alfalfa hay the effect is negligible upon the sorptive capacity.

\section{Sorption of Different Sample Sizes}

A set of 4 samples of chopped alfalfa was prepared in the 4-inch $\mathrm{x} 4$-inch baskets and the thickness varied. Thicknesses of samples were $7 / 8$ inch, $1 / 5$ inch, 3.25 inches. (There was only 1 representative of each one.) An attempt was made to keep as nearly a uniform density as possible. The density actually varied .232 grams or .28 per cent based on the smallest density. The material was dried at $120^{\circ} \mathrm{F}$ to a moisture content of 8 per cent wet basis. A plot of the data (Figure 16) showed no variation up to a moisture content of about 15 per cent 


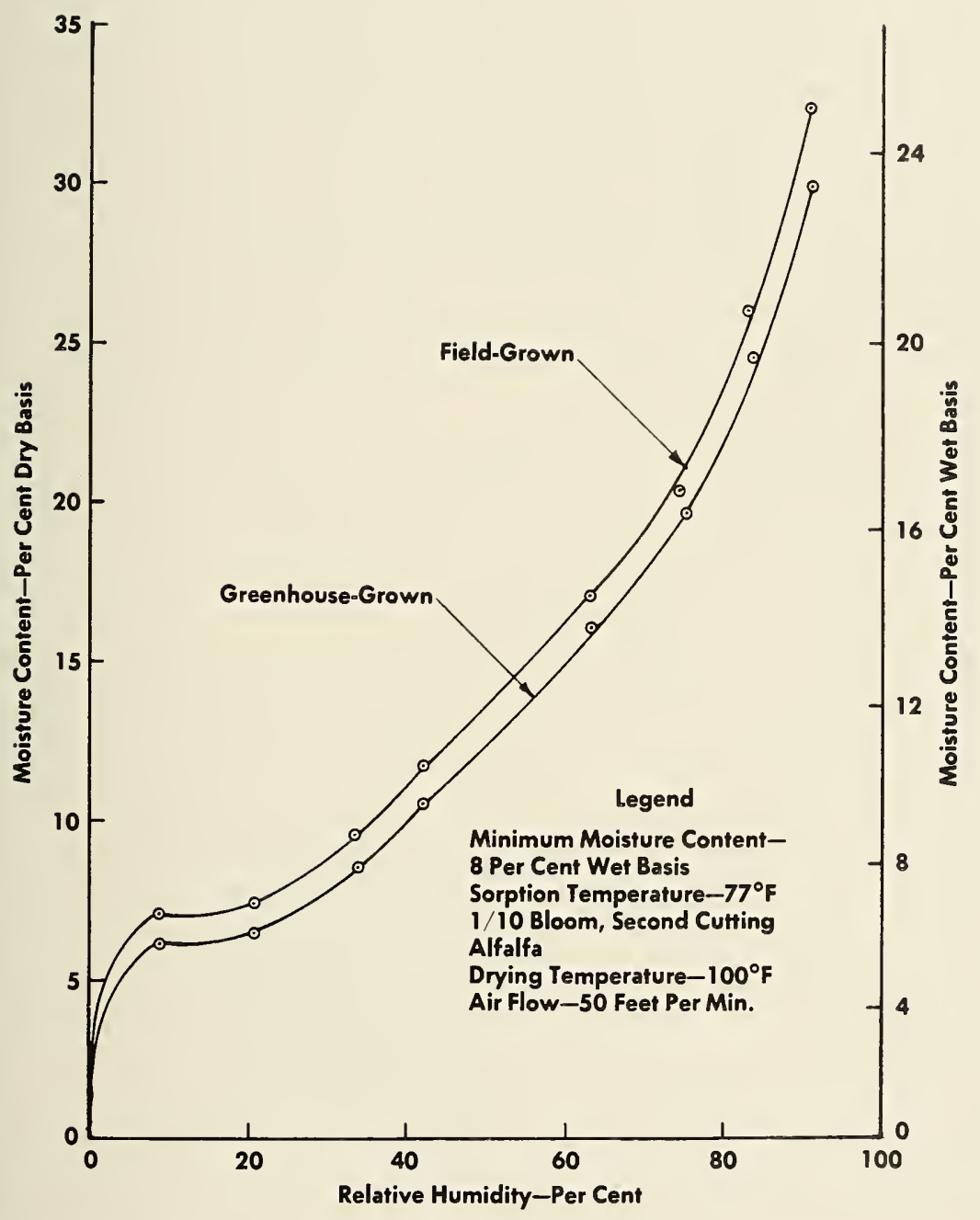

\section{FIGURE 12. STATIC SORPTION ISOTHERMS FOR GREENHOUSE AND FIELD-GROWN ALFALFA HAY.}




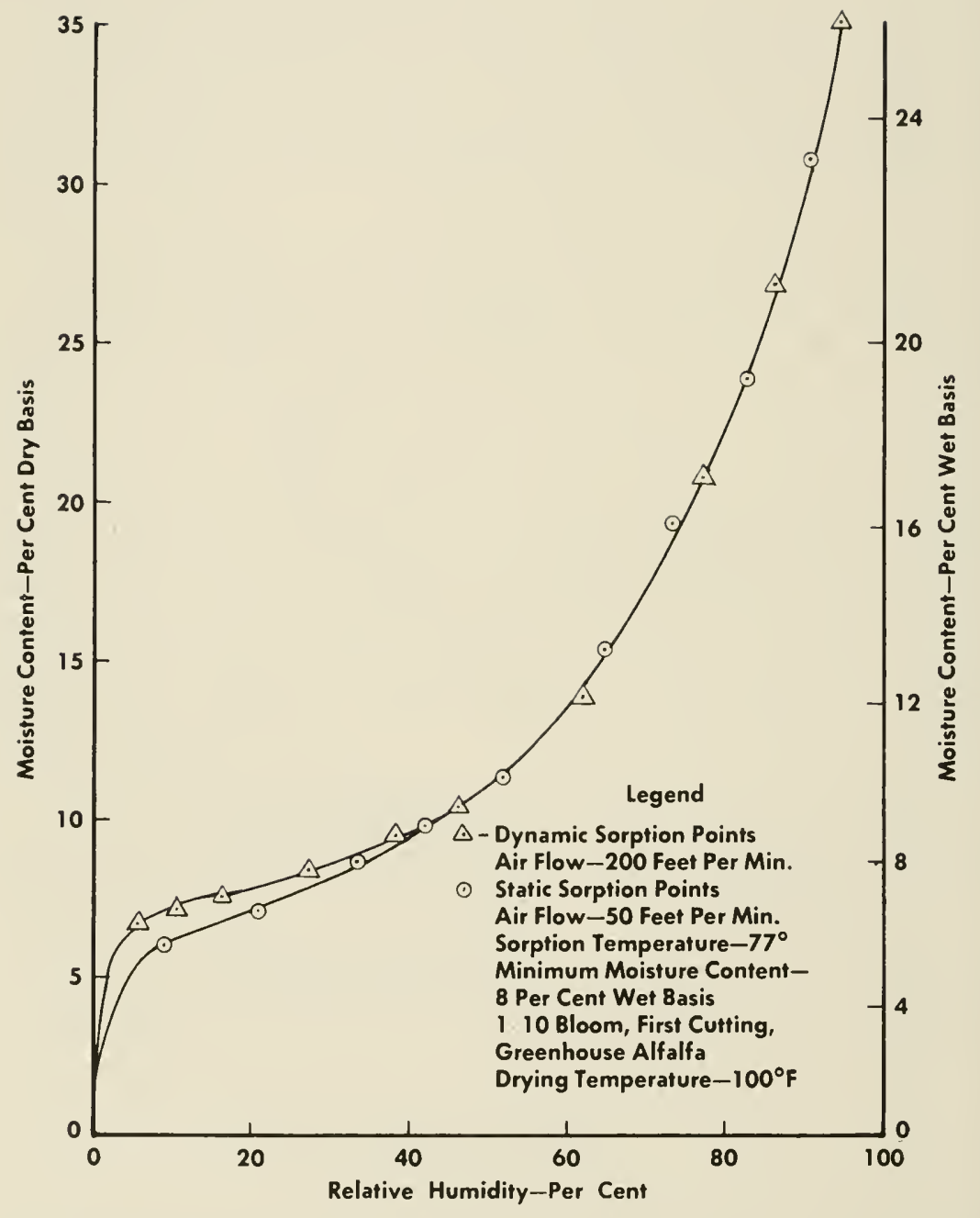

FIGURE 13. STATIC SORPTION ISOTHERMS FOR ALFALFA HAY WITH DIFFERENT RATES OF AIR FLOW. 
dry basis. From that point there seemed to be a direct relationship between sample density and sorptive capacity. The higher the density of the sample, the lower the regain.

No data were observed with respect to time other than the waiting period during which no weight change was detectable. There may have been a slow sorption taking place which resulted in so small a weight gain over the 2 hours used to establish whether or not samples were at equilibrium that it was undetected with the scales used. This coupled with the fact that there were no replications of the sample sizes render these data unreliable. The authors do not feel that any conclusions can be drawn from the data taken other than to say that for a specified sorption time there appears to be a trend toward inverse variation of sorptive capacity with density. Sample size does not appear to have an effect. 


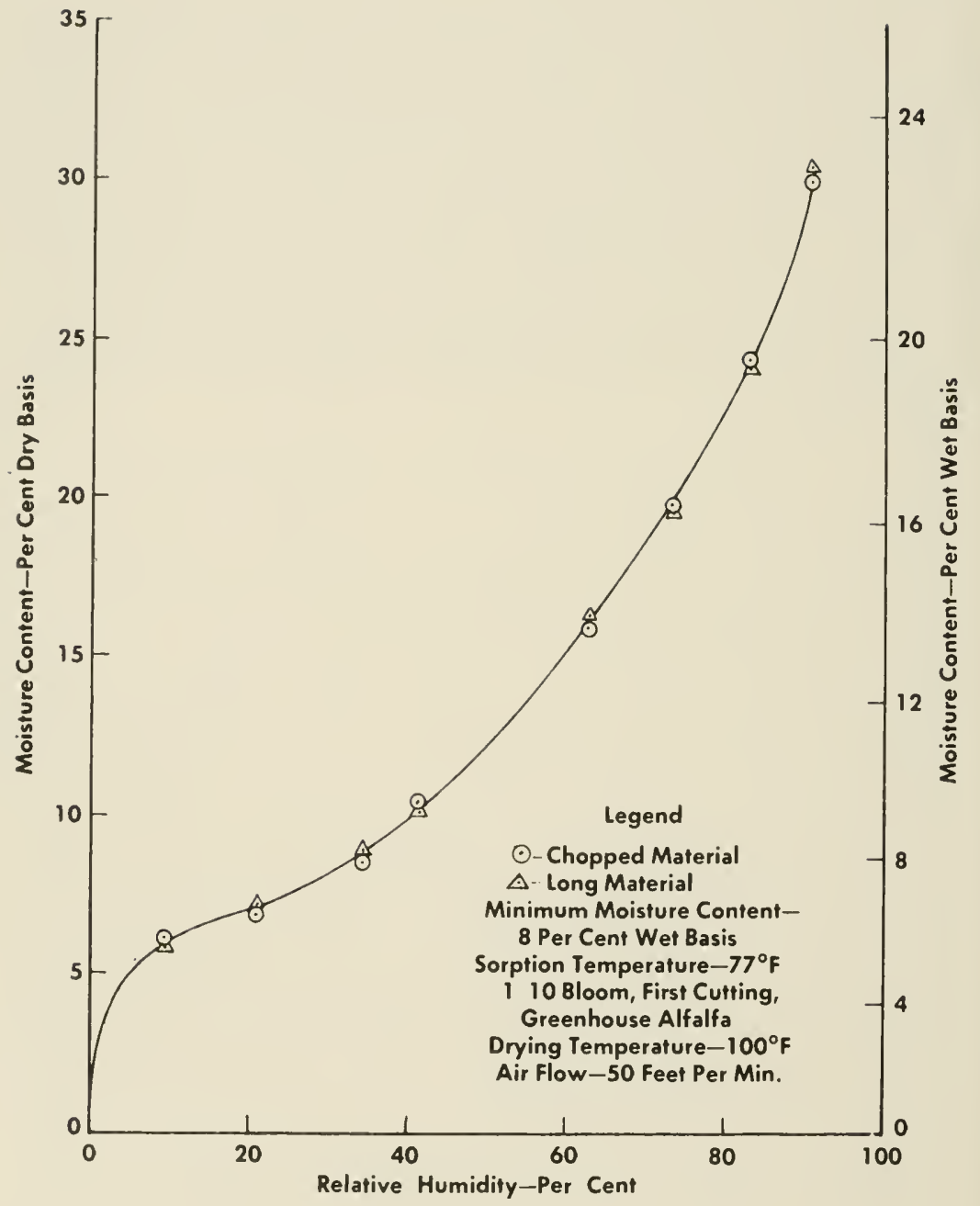

FIGURE 14. STATIC SORPTION ISOTHERMS FOR CHOPPED AND LONG ALFALFA HAY. 


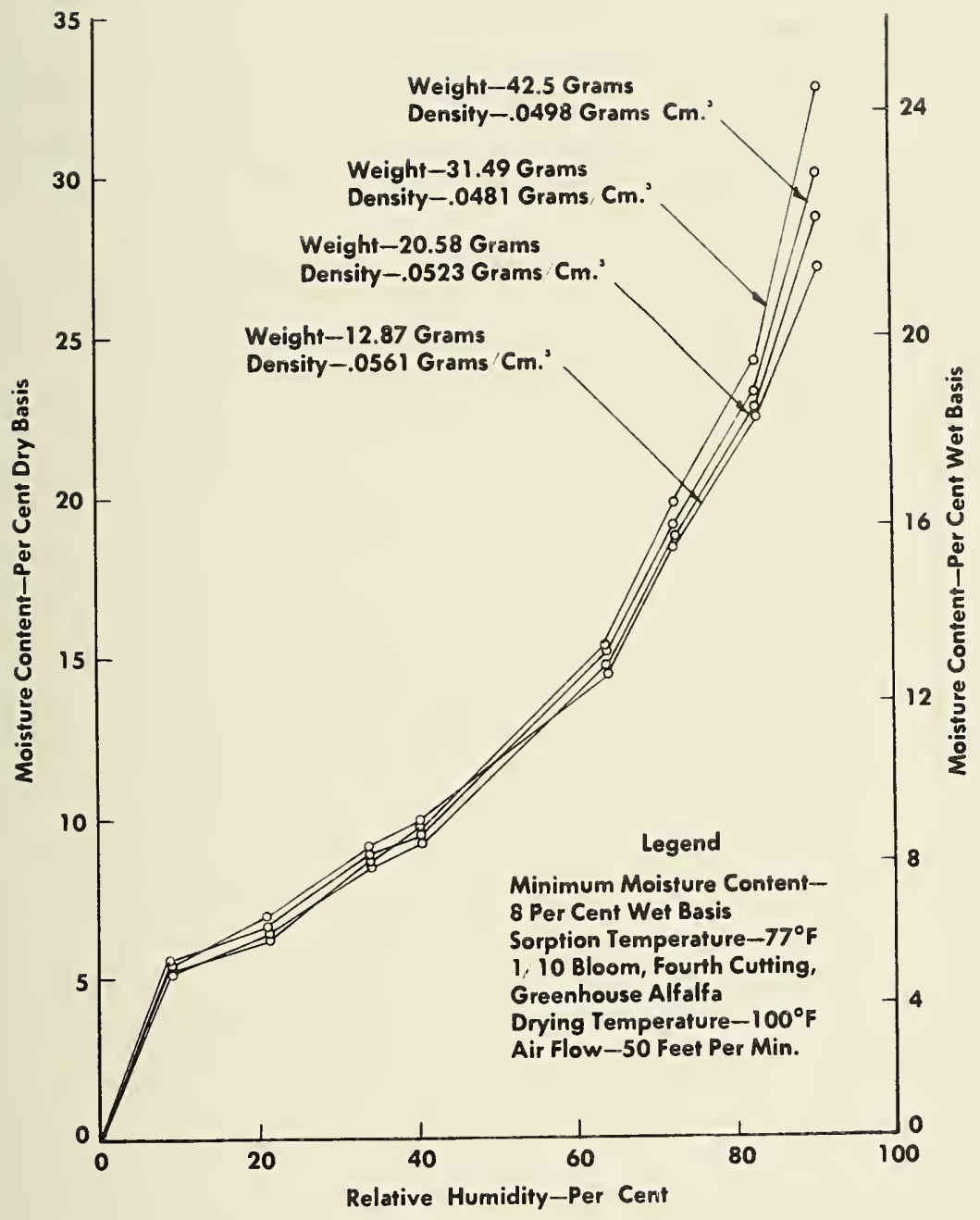

FIGURE 15. STATIC SORPTION ISOTHERMS FOR ALFALA
HAY SHOWING EFFECT OF SAMPLE SIZE AND
DENSITY. 


\section{Conclusions}

Past research indicates that sorptive capacity depends upon drying rate, leaf-stem ratio, variety, cutting schedule, soil moisture, stage of maturity, nutrient content, and shading.

It may be concluded from these investigations that the sorptive capacity of alfalfa hay is lowered by inereasing the drying temperature, decreasing the minimum moisture content to which the material is dried, and by growing material in an even temperature atmosphere such as a greenhouse.

The sorption conditions other than temperature and relative humidity investigated in this sturdy were found to have small effect on the sorption data of alfalfa. Higher air flow showed some vapor pressure increase for the low moisture contents, but on the whole, had very small effect. Sample size and chopping also had negligible effect. 


\section{Summary}

The object of the investigation was to determine some of the factors affecting the sorptive capacity of hygroscopic biological materials in an atmosphere of given temperature and relative humidity. The literature revealed that time, temperature, history, crystalline structure, sample size, drying rate, leaf-stem ratio for a given material, variety of material, cutting schedule, soil moisture, stage of maturity, and shading during the growing season all affect the sorptive capacity.

The material used was alfalfa hay. Sorption data were taken in both a static and dynamic controlled atmosphere for material which had been given specific treatments. High maximum drying temperature depressed the sorptive capacity as did a low minimum moisture content before sorption. Material grown in the field exceeded that grown in the greenhouse in capacity. A definite seasonal effect was found for material taken from the same plot.

The effect of chopping of material and sample size was investigated and found to be negligible. High air flow increased the sorption capacity slightly at low moisture contents.

The term "history of sorbent" is proposed as an all inclusive one which takes into account all the factors which affect the moisture sorption of hygroscopic materials. It is necessary to know this history in order to predict with a high degree of accuracy the sorption characteristic of the material. 


\section{Literature Cited}

1. Acheson, Donald T., "Vapor Pressures of Saturated Aqueous Salt Solutions." Paper presented at the International Symposium on Humidity and Moisture, Washington, D. C., May 1963.

2. Becker, H. A., and H. R. Sallans, "Desorption Isotherms of Wheat." Cereal Chemistry 33: 79-81, 1956.

3. Brunauer, Stephen, Adsorption of Gases and Vapors. Princeton, New Jersey: Princeton University Press, 1943, 1-161.

4. Brunauer, Stephen, P. H. Emmett, and E. Teller, "Adsorption of Gases in Multimolecular Layers." Joumal American Chemical Society 60: 309-11, 1938.

5. Collins, Edınond B., "Design of Equilibrium Moisture Test Equipment." Unpublished Thesis for M.S. Ag. E., Department of Agricultural Engineering, West Virginia University, 1961.

6. Dole, Malcolm, and A. D. McLaren, "Sorption of Water Vapor by Proteins and High Polymers." Journal American Chemical Society 69: 653-7, 1947.

7. Filby, E., and O. Maass, "Moisture Transfer in Solids." Canadian Journal of Research 10: 70-162, 1932.

8. McBain, H. L., Sorption of Gases by Solids. New York: McGrawHill Book Co., 1923. 1-119.

9. Sherwood, T. K., and E. W. Comings, "The Drying of Solids." Industrial and Engineering Chemistry 25: 311-13, 1933.

10. Smith, Sherman E., "The Sorption of Water Vapor by High Polymers." Journal American Chemical Society 69: 646-51, 1947. 

